O Haiti como locus ficcional da identidade caribenha: olhares transnacionais em Carpentier, Césaire e Glissant. Maria Helena Valentim Duca Oyama (Tese de doutorado, Universidade Federal Fluminense, 2009). Orientadora: Eurídice Figueiredo

\title{
A REVOLUÇÃO HAITIANA: REPRESENTAÇÃO E PARADIGMA
}

Os escritores e intelectuais caribenhos contemporâneos, em suas reflexōes sobre questôes identitárias, vêm abandonando cada vez mais o ângulo puramente local e privilegiando uma perspectiva relacional - no sentido que dá ao termo o escritor martinicano Édouard Glissant - que enfatiza os encontros e as interfaces entre essas diferentes histórias, sem esquecer os laços problemáticos com as antigas metrópoles. Daí o interesse de um trabalho como O Haiti como locus ficcional da identidade caribenha: olhares transnacionais em Carpentier, Césaire et Glissant, que se elabora justamente segundo esse eixo.

Maria Helena Valentim Duca Oyama, em sua tese, examina como a Revolução haitiana - ou como prefere a autora, a Revolução de Saint Domingue - transformou-se, no século XX, para outros escritores caribenhos, em um paradigma que lhes permitiu refletir sobre suas problemáticas particulares. Além disso, a autora analisa o tratamento do tema em textos de autores franceses do século XIX que, obviamente por razões diversas, também elegeram essa revolução como objeto. Como explicita a autora, seu objetivo é "fazer uma análise da representação do Haiti e de seus heróis a fim de mostrar como ele se tornou o locus ficcional da identidade caribenha” (p. 13).

O corpus principal é constituído pelas seguintes obras: o romance El reino desse mundo (1949), do cubano Alejo Carpentier, o ensaio Toussaint Louverture. La révolution française et le problème colonial (1962), a peça de teatro La tragédie du roi Christophe (1963), do martinicano Aimé Césaire e a peça Monsieur Toussaint (1961), do também martinicano Edouard Glissant. A autora trabalha ainda com o que chama de corpus complementar: o drama Toussaint Louverture (1839-1850), de Alphonse de Lamartine e o romance Bur-Jargal (1818-1826), de Victor Hugo.

Trata-se de um tema relevante, na medida em que, como explica Duca Oyama, apoiada em Walter Mignolo, a Revolução de 
Saint-Domingue "é um elemento crucial para a formação da modernidade caribenha e latino-americana", já que introduz "a ideia de resistência (...) com uma dimensão internacional” (pp. 12-13). Mas, embora emblemático por fazer do Caribe uma lugar de contestação da ordem colonizadora, o acontecimento histórico foi silenciado pela ação de "duas ideologias geopolíticas e linguísticas dominantes: a Anglo-americana e a América Hispânica”. Donde o isolamento do Haiti, depois da independência.

A tese, cuja fundamentação teórica se adequa bem ao objeto, desperta interesse e se lê com prazer, por ser bem escrita e bem organizada. A hipótese é desenvolvida em três etapas. $O$ primeiro capítulo é dedicado aos principais projetos de construções identitárias no Caribe e na América Latina, com o propósito de mostrar os contextos intelectuais distintos dos quais emergem as diferentes apropriações da Revolução haitiana e de seus heróis: o real maravilhoso de Carpentier, o indigenismo de Jean-Price-Mars e Jacques Roumain, a negritude de Césaire, a antilhanidade e a crioulização de Glissant, além da noção de geopoética caribenha de Daniel Maxim.

O segundo capítulo constitui uma apresentação analítica do contexto histórico. São abordados os acontecimentos, seus protagonistas e as consequências da Revolução, como uma preparação para a leitura das obras que elegeram o Haiti como locus ficcional. São ressaltadas as ambiguidades tanto do gesto revolucionário quanto de seus heróis.

O terceiro capítulo apresenta e analisa as diferentes encenaçóes desse locus ficcional, em acordo com os projetos poéticos e políticos de cada um desses autores, apontando para o diálogo, o entrecruzamento tanto desses pensamentos quanto de suas manifestaçóes estéticas.

A diversidade genérica do corpus pode ser motivo de incômodo para alguns, já que a questão não é, de fato, problematizada, o que, em alguns - poucos - momentos, parece colocar certas dificuldades para a análise crítica comparativa de alguns aspectos das obras. É o caso da questão da coexistência de várias temporalidades do mundo colonial, que se traduziria, na narrativa de Carpentier, segundo Maria Helena, pelo procedimento da colagem, estratégia que é bem desenvolvida e bem analisada por ela. Porém, ao tentar abordar a mesma questão, na obra de Glissant, a autora se limita a afirmar que "a temporalidade é subvertida, na medida em que as constantes retomadas das falas dos personagens remontam a outras épocas, ligadas às insurreiçôes" (p. 111), sem realmente desenvolver o ponto. A análise, aqui, parece se tornar inviável, na 
medida em que a estética do teatro se pauta em estratégias diferentes daquelas que são mobilizadas na narrativa. São apresentadas, na "Introdução", duas justificativas para esse hibridismo genérico. De um lado, a escolha de gêneros diversos para compor o corpus tornaria o trabalho "coerente com as teorias modernas que defendem a abolição das fronteiras entre gêneros literários" (p. 14). De outro, "a representação identitária do Haiti, e de seus heróis (...), é delineada pelo fio histórico da revolução de Saint Domingue. Esse fio condutor permite-nos afirmar que, se as tomarmos cronologicamente, uma complementa, aprofunda ou expande a outra, como se a intenção de cada autor fosse dar continuidade à obra anterior" (p. 18). Depreende-se da segunda justificativa que o eixo de análise escolhido é antes temático-histórico e, nesse sentido, despreza as distinções formais tradicionais, para se interessar pelos diversos modos de apropriação política do acontecimento. A opção de Glissant e Césaire pelo gênero teatral, nesse sentido, como explica a autora (pp. 16-17), obedeceria à necessidade de criar uma consciência coletiva, de se aproximar do povo, o que, para os dois autores seria uma urgência naquele momento histórico.

Percebe-se um pequeno desequilíbrio no tratamento do corpus no que diz respeito à obra Monsieur Toussaint, de Glissant, que fica um pouco esquecida, em proveito das análises bem desenvolvidas e fundamentadas das outras obras que constituem o corpus principal. Algumas propostas teóricas esboçadas inicialmente, como "o conceito de discurso 'estereótipo", de Homi Bhabha (p. 15), não são retomadas no momento da análise do corpus. Entretanto, isso não prejudica de fato esse trabalho, marcadamente glissantiano, que nunca perde de vista seu apoio teórico principal. A começar pela proposta metodológica da autora: "associ[ar] o tempo ficcional com o tempo histórico" (p. 18) que se encontra em perfeito acordo com a epígrafe do primeiro capítulo, ponto de partida para a reflexão. No fragmento escolhido, Glissant propõe o resgate do passado através de uma "visão profética", ou seja, poética, única possibilidade, segundo ele, de restituir a uma comunidade uma história ocultada pela história oficial. O que nos parece mais relevante porém é que o próprio argumento desenvolvido na tese se constrói na esteira do pensamento do autor antilhano. A noção de Relação, tal como foi exposta em Poétique de la relation (1990), inspira o diálogo entre as distintas formas de apropriação de um acontecimento emblemático, "os projetos poéticos e políticos se entrecruzam, 
num verdadeiro processo de relação, de rizomas, na medida em que conceitos ou noções iniciais se completam e aprofundam"(p. 147). Também outra noção glissantiana, a de Détour (Desvio), pode iluminar o fato de todos esses autores reescreverem, cada qual a seu modo, a Revolução haitiana como mediação para pensar suas questóes identitárias particulares, se opor às interpretações e projetos existentes e propor novas soluçôes. Assim, como explica a autora, duas visões políticas se confrontam nas peças de Césaire e de Glissant. Na primeira, o personagem Toussaint Louverture é "um mártir, um herói vítima, que acertou nas suas tomadas de decisões 'de circunstância'” (p. 150), interpretação que não deixa de ser uma justificativa para a decisão política do próprio Césaire em aceitar a Lei de Departamentalização da Martinica (1946), fazendo dos habitantes da ilha cidadãos franceses. Em Monsieur Toussaint, a crítica ao protagonista se transforma em mediação para criticar a própria decisão de Césaire, construindo a figura de "um dirigente confuso" (p. 151). Glissant propõe que só uma reflexão coletiva pode levar a uma saída, o que teria de passar forçosamente pelo reconhecimento de uma identidade marcada pela heterogeneidade, pela convergência de várias matrizes. Essas observações permitem ver que, nesse trabalho, o eixo teórico que se elegeu preferencialmente, o pensamento de Glissant, funciona efetivamente como elemento estruturador e argumentativo.

A tese de Maria Helena Valentim Duca Oyama, pela relevância do tema, pela abrangência da proposta, pela escolha do corpus, pela leitura crítica das obras, pela documentação e fundamentação teórica, nos parece constituir um texto de referência para pesquisadores que desejem explorar as questôes identitárias e as manifestações estéticas caribenhas.

Jovita Maria Gerheim Noronha (UFJF) 